\title{
Evaluation of the genotoxic potential of Austroplenckia populnea (Reiss) Lundell chloroform fraction from barkwood extract in rodent cells in vivo
}

\author{
Ribeiro, JC. a , Andrade, SF. ${ }^{\mathrm{b}}$, Bastos, JK. ${ }^{\mathrm{c}}$ and Maistro, EL. ${ }^{\mathrm{d}}$

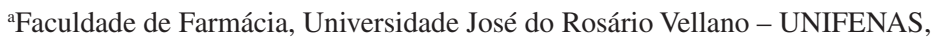 \\ Alfenas, MG, Brazil

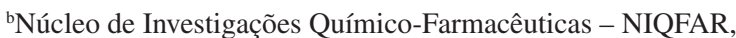 \\ Universidade do Vale do Itajaí - UNIVALI, Itajaí, SC, Brazil \\ ${ }^{c}$ Faculdade de Ciências Farmacêuticas de Ribeirão Preto - FCFRP, \\ Universidade de São Paulo - USP, Ribeirão Preto, SP, Brazil \\ ${ }^{\mathrm{d}}$ Departamento de Fonoaudiologia, Faculdade de Filosofia e Ciências - FFC, \\ Universidade Estadual Paulista - UNESP, CEP 17525-900, Marília, SP, Brazil \\ *e-mail: edson.maistro@marilia.unesp.br
}

Received April 1, 2008 - Accepted April 25, 2008 - Distributed November 30, 2009

\begin{abstract}
The genotoxic effect of the Austroplenckia populnea chloroform fraction from barkwood extract was tested in vivo on peripheral blood cells of Swiss mice with the comet assay (SCGE), and the clastogenic effect was investigated on peripheral blood cells of Swiss mice and bone marrow cells of Wistar rats, with the micronucleus and chromosome aberrations tests. The animals were treated by gavage with 3 concentrations of the extract: 300,600 and $900 \mathrm{mg} \cdot \mathrm{kg}^{-1}$. Peripheral blood cells of Swiss mice were collected 4 and 24 hours after the treatment to the SCGE assay and 48 and 72 hours to the micronucleus test. Bone marrow cells of Wistar rats were collected 24 hours after the treatment to the micronucleus and chromosome aberration tests. The results showed that the A. populnea chloroform fraction induced an increase in the average number of DNA damage in peripheral blood cells at the three concentrations tested, but this increase was not statistically significant. In the micronucleus and chromosome aberrations test, no significant increase was observed in the mean number of micronucleated polychromatic erythrocytes (MNPCE) of Swiss mice or MNPCE or chromosome aberrations for the rat bone marrow cells, for any of the tested doses. Our findings enable us to conclude that by the comet assay, A. populnea chloroform fraction from barkwood extract showed no genotoxic effects, and by the micronucleus and chromosome aberration tests, the extract fraction showed no clastogenic/aneugenic effects on the rodent cells tested.
\end{abstract}

Keywords: Austroplenckia populnea, celastraceae, micronucleus test, single cell gel electhrophoresis, chromosome aberrations.

\section{Avaliação do potencial genotóxico da fração clorofórmica de cascas do caule de Austroplenckia populnea em células de roedores in vivo}

\section{Resumo}

O possível efeito genotóxico da fração clorofórmica de cascas de caule de Austroplenckia populnea foi testado in vivo em células do sangue periférico de camundongos Suíços pelo ensaio cometa, e o seu possível efeito clastogênico foi investigado em células de sangue periférico de camundongos Suíços e células da medula óssea de ratos Wistar, respectivamente pelos testes do micronúcleo e de aberrações cromossômicas. Os animais foram tratados por via oral com três concentrações do extrato: 300, 600 e $900 \mathrm{mg} \cdot \mathrm{kg}^{-1}$ de peso corpóreo. Células do sangue periférico dos camundongos foram coletadas 4 e 24 horas após o tratamento para a realização do ensaio cometa, e 48 e 72 horas para o teste do micronúcleo. Células da medula óssea dos ratos Wistar foram coletadas 24 horas após o tratamento para os testes do micronúcleo e de aberrações cromossômicas. Os resultados mostraram que a fração clorofórmica do extrato de A. populnea induziu um pequeno aumento no número médio de danos ao DNA nas células sanguíneas nas três concentrações testadas, mas tal aumento não foi estatisticamente significativo. Nos testes do micronúcleo e de aberrações cromossômicas não houve um aumento significativo no número médio de eritrócitos policromáticos micronucleados (EPM) dos camundongos, bem como nos EPM e aberrações cromossômicas nas células da medula óssea dos ratos, em 
nenhuma das doses testadas. Nossos resultados nos permitem concluir que, pelo ensaio cometa, a fração clorofórmica de cascas do caule de A. populnea não apresentou efeito genotóxico, e, pelos testes do micronúcleo e de aberrações cromossômicas, o extrato não mostrou efeitos clastogênicos e/ou aneugênicos nas células analisadas dos roedores.

Palavras-chave: Austroplenckia populnea, celastraceae, teste do micronúcleo, ensaio cometa, aberrações cromossômicas.

\section{Introduction}

There is considerable interest in determining the risks that plant extracts may pose to health, since many of these extracts contain compounds known to cause diseases or even death to animals and humans by acting as natural mutagens and carcinogens (Araújo et al., 1999; Burim et al., 1999; Chacon et al., 2002; Espósito et al., 2005, Maistro et al., 2005).

Austroplenckia populnea (Reiss) Lundell is a plant of the Brazilian Cerrado or Savannah region, which belongs to the Celastraceae family. This botanical family includes several plant species that have been widely used in traditional medicine for their antiulcerogenic, analgesic, male antifertility and antiinflammatory properties, among others (Corrêa, 1985). A. populnea is commonly known in Portuguese as "marmelinho do campo, mangabeira-brava, mangabarana" and "vime", and is a folk medicine used as an anti-dysenteric and anti-rheumatic (Corrêa, 1985). Antiulcerogenic and analgesic effects of the leaf extracts have been reported in mice (Seito et al. 2002), and Mazaro et al. (2000) reported a decrease in sperm count following treatment of rats with this extract. Studies involving chemical aspects of leaf preparations revealed the presence of friedelane and oleanane triterpenes and sesquiterpenes (Vieira-Filho et al., 2001).

The phytochemical study of the A. populnea crude barkwood extract resulted in isolation and/or identification of steroids (stigmasterol, campesterol, $\beta$-sitosterol) and triterpenes (populnoic acid, methyl populnonate, epitaraxerol, $\beta$-amirine, lupeol acetate, $\beta$-friedalanol and friedelin) (Andrade, 2005). These mixed compounds showed anti-inflammatory, analgesic and antiulcer activities, but their hexane, chloroform and ethyl acetate fractions showed a decrease in these activities (Andrade, 2005).

Zanoni et al. (2005) evaluated, for the first time, the mutagenic potential of $A$. populnea extract and observed that crude hydroalcoholic barkwood extract showed a slight but statistical significant clastogenic effect in the bone marrow cells of Wistar rats. On the other hand, A. populnea leaf extract did not induce clastogenicity in the bone marrow cells of Wistar rats (Pugliesi et al., 2007).

Considering the phytotherapeutic potential of the A. populnea extracts and the mutagenic antecedent of one barkwood extract, we are developing several studies to further evaluate the genotoxicity of some A. populnea extracts/fractions. In this report we determined the mutagenic potential of the A. populnea chloroform fraction from crude barkwood extract in peripheral blood and bone marrow cells in vivo in rodents, using the Single Cell Gel Electrophoresis (SCGE), micronucleus and chromosome aberration tests.

\section{Material and Methods}

\subsection{Plant material}

The plant material of Austroplenckia populnea was collected in the Cerrado, at Botucatu, in the state of São Paulo, Brazil. The plant was identified, and a voucher specimen ( $\mathrm{n}^{\circ}$ 20415) was deposited in the BOTU herbarium of the Bioscience Institute of Paulista State University (IB, UNESP). The hydro-alcohol extract was obtained from the bark wood $(3,248.55 \mathrm{~g})$, which was dried and pulverized, to yield $405.77 \mathrm{~g}$, and cold macerated with $96 \%$ ethanol for 48 hours (three times). The final filtrate was concentrated (rota-evaporator) to yield the hydro-alcoholic extract. The hydro-alcoholic (EtOH) crude extract was partitioned between hexane, $\mathrm{CHCl}_{3}$ and ethyl acetate (EtOAC), to yield 8.0, 9.5 and $98.17 \mathrm{~g}$ of fractions, respectively.

\subsection{Chemicals}

The agent N-nitroso-N-ethylurea (ENU, CAS No. 759-73-9) was used as the DNA damaging agent in the SCGE and micronucleus assays using Swiss mice. It was dissolved in phosphate-buffer at $\mathrm{pH} 6$. The alkylating agent cyclophosphamide (CPA, CAS: C 0768, Sigma) was used as the clastogenic agent in the micronucleus and chromosome aberrations assay using Wistar rats. The other principal chemicals used were obtained from the following suppliers: normal melting point (NMP) agarose (Cat. No. 15510-019: Invitrogen); Low melting point (LMP) agarose (Cat. No. 15517-014: Invitrogen); Sodium salt N-lauroyl sarcosine (L-5125: Sigma) and EDTA (Merck).

\subsection{Animals and assay procedures}

Experiments were carried out using six-week-old male Wistar rats (Rattus norvegicus), weighing approximately $100 \mathrm{~g}$, and twelve-week-old male albino Swiss mice (Mus musculus) weighing 25-30 g. The animals were acquired from the animal house of the Jose do Rosario Vellano University (UNIFENAS), and kept in polyethylene boxes $(n=6)$, in a climate-controlled environment $\left(25 \pm 4{ }^{\circ} \mathrm{C}, 55 \pm 5 \%\right.$ humidity) with a 12 hours, light/dark cycle (7:00 AM to 7:00 PM). Food (LABINA - PURINA) and water were available ad libitum. The rats and mice were divided into experimental groups of six 
animals each. Austroplenckia populnea chloroform fraction was administered at a single dose of $0.5 \mathrm{~mL}$ by gavage, at concentrations of 300,600 and $900 \mathrm{mg} \cdot \mathrm{kg}^{-1}$ body weight, selected on the basis of acute toxicity studies in mice using A. populnea leaf extract (Seito et al. 2002). The negative control groups (both mice and rats) received distilled water. The positive control group using Swiss mice received $50 \mathrm{mg}$ of N-nitroso-N-ethylurea/kg (ENU), and the Wistar rats received $50 \mathrm{mg}$ of cyclophosphamide/g. The rats were injected intraperitoneally with $0.5 \mathrm{~mL}$ of $0.16 \%$ colchicine 90 minutes, prior to euthanasia 24 hours after the experiments. Both femur bones were excised and the bone marrow flushed into test tubes using a syringe. For the micronucleus (MN) assay, the bone marrow cells from one femur were prepared as recommended by Schimid (1976). The slides were coded, fixed with methanol and stained with Giemsa solution. 2 thousand polychromatic erythrocytes (PCE) from each animal were scored for micronucleus $(\mathrm{MN})$ presence. Bone marrow preparations from the other femur were used for the analysis of chromosome aberrations in metaphase cells, using the technique of Ford and Hamerton (1956). 100 metaphases per animal (600 metaphases per group) were analyzed, in order to determine the number of chromosomal aberrations in a blind test. The chromosomal aberrations were classified according to Savage (1976), as gaps, breaks, deletions, fragments, rings and dicentric chromosomes. Since the cytogenetic significance of the gaps is still not well established, the statistical analyses were carried out excluding gaps. The mitotic index (MI) was obtained by counting the number of mitotic cells in the 1,000 cells analyzed per animal. For the micronucleus (MN) assay on Swiss mice, peripheral blood was collected from the orbital vein, 48 and 72 hours after the treatment, then blood smear slides were prepared. All the slides were coded, fixed with methanol and stained with Giemsa solution. For micronucleus (MN) presence, two thousand polychromatic erythrocytes were scored from each Wistar rat and four thousand peripheral erythrocytes from each Swiss mouse (2,000 cells from the 48 hours blood sample and 2,000 cells from the 72 hours blood sample) (MacGregor et al., 1980).

The Single cell gel electrophoresis test (SCGE) was carried out using the method described by Speit and Hartmann (1999), which is based on the original work of Singh et al. (1988) and includes modifications introduced by Klaude et al. (1996), with some additional modifications. 4 and 24 hours after the treatment, peripheral blood cells from Swiss mice were taken. A $10 \mu \mathrm{L}$ aliquot of the peripheral blood was mixed with $120 \mu \mathrm{L}$ of $0.5 \%$ low melting point agarose at $37{ }^{\circ} \mathrm{C}$, and rapidly spread onto microscope slides pre-coated with $1.5 \%$ normal melting point agarose. Coverslips were added and the slides were allowed to gel at $4{ }^{\circ} \mathrm{C}$, for 20 minutes. The coverslips were gently removed and the slides were then immersed in cold, freshly prepared lysing solution consisting of $89 \mathrm{~mL}$ of a stock solution $(2.5 \mathrm{M} \mathrm{NaCl}$, $100 \mathrm{mM}$ EDTA, $10 \mathrm{mM}$ Tris, $\mathrm{pH}$ set to 10.0 with $\sim 8 \mathrm{~g}$ solid $\mathrm{NaOH}, 890 \mathrm{~mL}$ of distilled water and $1 \%$ sodium lauryl sarcosine), plus $1 \mathrm{~mL}$ of Triton X-100 (Merck) and $10 \mathrm{~mL}$ of DMSO. The slides, which were protected from light, were left to stand at $4{ }^{\circ} \mathrm{C}$ for 1 hour and then placed in the gel box, positioned at the anode end, and left in a high $\mathrm{pH}(>13)$ electrophoresis buffer $(300 \mathrm{mM}$ $\mathrm{NaOH}$ per $1 \mathrm{mM}$ EDTA, prepared from a stock solution of $10 \mathrm{~N} \mathrm{NaOH}$ and $200 \mathrm{mM}, \mathrm{pH} 10.0$, EDTA) at $4{ }^{\circ} \mathrm{C}$ for 20 minutes before electrophoresis, to allow the DNA to unwind. The electrophoresis run was performed in an ice bath $\left(4{ }^{\circ} \mathrm{C}\right)$ for 20 minutes at $25 \mathrm{~V}$ and $300 \mathrm{~mA}$. The slides were then submerged in a neutralization buffer (0.4 M Tris- $\mathrm{HCl}, \mathrm{pH} 7.5)$ for 15 minutes, dried at room temperature and fixed in $100 \%$ ethyl alcohol for $10 \mathrm{~min}$ utes. The slides were dried and stored at least overnight before staining. For the staining process, the slides were briefly rinsed in distilled water, covered with $30 \mu \mathrm{L}$ of $1 \times$ ethidium bromide staining solution prepared from a $10 \times$ stock $\left(200 \mu \mathrm{g} . \mathrm{mL}^{-1}\right)$, and covered with a coverslip. The material was evaluated immediately at $400 \times$ magnification, using a fluorescence microscope (Nikon) with a $515-560 \mathrm{~nm}$ excitation filter and a $590 \mathrm{~nm}$ barrier filter. The Animal Bioethical Committee of the UNIFENAS, Brazil, approved the present study on November, 2004 (protocol number 11A/2004), in accordance with the Federal Government legislation on animal care.

\subsection{Scoring procedures and data evaluation}

The extent and distribution of DNA damage indicated by the SCGE assay was evaluated by examining at least 200 randomly selected and non-overlapping cells on the slides per each animal. These cells were visually scored according to tail size, into four classes, as follows: (1) class 0: undamaged, with no tail; (2) class 1 : with a tail shorter than the diameter of the head (nucleus); (3) class 2 : with a tail length of 1 to $2 \times$ the diameter of the head; and (4) class 3: with a tail longer than $2 \times$ the diameter of the head. Comets with no heads and images with nearly all DNA in the tail, or with a very wide tail, were excluded from evaluation because they probably represent dead cells (Hartmann and Speit 1997). The total score for 200 comets was obtained by multiplying the number of cells in each class by the damage class, ranging from 0 (all undamaged) to 600 (all maximally damaged).

\subsection{Statistical Analysis}

The data obtained from the micronucleus and SCGE assays were submitted to One-way analysis of variance test (ANOVA) and the Tukey-Kramer multiple comparison test (Sokal and Rohlf 1995), using the GraphPad Instat ${ }^{\circledR}$ software (version 3.01). The results were considered statistically significant at $\mathrm{p}<0.05$.

\section{Results}

Table 1 shows the effects of a 4 and 24 hours treatment with the extract on DNA migration in peripheral blood leukocytes from Swiss mice in the comet as- 
Table 1. DNA migration in the comet assay for the assessment of genotoxicity of Austroplenckia populnea chloroform fraction in peripheral blood leukocytes (collected 4 and 24 hours after the treatment) from male Swiss mice ( $\mathrm{n}=6$ per group) in vivo.

\begin{tabular}{|c|c|c|c|c|c|c|}
\hline \multirow[t]{2}{*}{ Treatments } & & \multicolumn{4}{|c|}{ Comet class $($ Mean \pm SD) } & \multirow[t]{2}{*}{ Scores } \\
\hline & Total $^{1}$ & $\mathbf{0}$ & 1 & 2 & 3 & \\
\hline \multicolumn{7}{|l|}{ Control } \\
\hline 4 hours & $12.1 \pm 2.4$ & $187.8 \pm 2.48$ & $11.3 \pm 2.16$ & $0.8 \pm 0.40$ & 0.0 & $13.0 \pm 2.8$ \\
\hline 24 hours & $11.3 \pm 3.5$ & $188.6 \pm 3.55$ & $11.0 \pm 3.34$ & $0.3 \pm 0.81$ & 0.0 & $11.6 \pm 3.9$ \\
\hline \multicolumn{7}{|c|}{ A. populnea $\left(300 \mathrm{mg} \cdot \mathrm{kg}^{-1}\right)$} \\
\hline 4 hours & $20.5 \pm 3.9$ & $179.5 \pm 3.93$ & $17.8 \pm 3.60$ & $2.6 \pm 1.50$ & 0.0 & $23.1 \pm 4.7$ \\
\hline 24 hours & $18.5 \pm 7.7$ & $181.5 \pm 7.74$ & $18.6 \pm 7.65$ & $0.3 \pm 0.51$ & 0.0 & $19.0 \pm 8.0$ \\
\hline \multicolumn{7}{|c|}{ A. populnea $\left(600 \mathrm{mg} \cdot \mathrm{kg}^{-1}\right)$} \\
\hline 4 hours & $16.3 \pm 7.3$ & $183.6 \pm 7.36$ & $15.3 \pm 6.31$ & $0.8 \pm 0.98$ & $0.16 \pm 0.40$ & $17.5 \pm 8.8$ \\
\hline 24 hours & $15.0 \pm 7.3$ & $185.0 \pm 7.37$ & $14.1 \pm 7.52$ & $0.6 \pm 0.81$ & $0.16 \pm 0.40$ & $16.3 \pm 7.3$ \\
\hline \multicolumn{7}{|c|}{ A. populnea $\left(900 \mathrm{mg} \cdot \mathrm{kg}^{-1}\right)$} \\
\hline 4 hours & $20.3 \pm 4.7$ & $179.6 \pm 4.76$ & $19.5 \pm 5.08$ & $0.6 \pm 0.81$ & $0.16 \pm 0.40$ & $21.3 \pm 4.6$ \\
\hline 24 hours & $17.8 \pm 9.6$ & $182.1 \pm 9.64$ & $17.6 \pm 9.87$ & 0.0 & $0.16 \pm 0.40$ & $18.1 \pm 9.2$ \\
\hline \multicolumn{7}{|c|}{ ENU (50 mg.kg $\left.{ }^{-1}\right)$} \\
\hline 4 hours & $180.5 * * \pm 5.3$ & $19.5 * * \pm 5.3$ & $166.0 * * \pm 9.01$ & $12.8^{* *} \pm 4.4$ & $1.6^{* *} \pm 1.03$ & $196^{* *} \pm 4.6$ \\
\hline 24 hours & $158.6^{* *} \pm 13$ & $41.3 * * \pm 13.5$ & $149.0 * * \pm 13.2$ & $8.3^{* *} \pm 1.36$ & $1.3 * * \pm 0.81$ & $170 * * \pm 12.9$ \\
\hline
\end{tabular}

*Significantly different from the negative control $(\mathrm{p}<0.05)$; * Significantly different from the negative control $(\mathrm{p}<0.001)$; and ${ }^{1}$ Total number of damaged cells (class $1+2+3$ )

Table 2. Number of micronucleated polychromatic erythrocytes (MNPCEs) observed in bone marrow cells of male (M) Wistar rats and in the peripheral blood cells of male (M) Swiss mice treated with an Austroplenckia populnea chloroform fraction, and respective controls. For each time period (24, 48 and 72 hours) 2000 cells were analysed. SDM $=$ standard deviation of the mean.

\begin{tabular}{|c|c|c|c|c|c|c|c|c|c|}
\hline \multirow[t]{2}{*}{ Treatments } & \multirow{2}{*}{$\begin{array}{l}\text { Animal } \\
\text { species }\end{array}$} & \multirow{2}{*}{$\begin{array}{c}\text { Cell } \\
\text { collect time }\end{array}$} & \multicolumn{6}{|c|}{ Number of MNPCEs per Animal } & \multirow{2}{*}{$\begin{array}{c}\text { MNPCE } \\
(\text { Mean } \pm \text { SDM }\end{array}$} \\
\hline & & & M1 & M2 & M3 & M4 & M5 & M6 & \\
\hline \multirow[t]{3}{*}{ Control } & Wistar rat & 24 hours & 5 & 3 & 2 & 5 & 7 & 3 & $4.1 \pm 1.83$ \\
\hline & Swiss mice & 48 hours & 1 & 1 & 1 & 0 & 2 & 3 & $1.3 \pm 1.0$ \\
\hline & Swiss mice & 72 hours & 1 & 2 & 0 & 1 & 1 & 0 & $0.8 \pm 0.75$ \\
\hline \multirow{3}{*}{$\begin{array}{l}\text { A. populnea } \\
\left(300 \mathrm{mg} \cdot \mathrm{kg}^{-1}\right)\end{array}$} & Wistar rat & 24 hours & 3 & 3 & 4 & 2 & 2 & 4 & $3.0 \pm 0.89$ \\
\hline & Swiss mice & 48 hours & 2 & 2 & 1 & 1 & 2 & 2 & $1.6 \pm 0.51$ \\
\hline & Swiss mice & 72 hours & 2 & 1 & 1 & 3 & 2 & 0 & $1.5 \pm 1.0$ \\
\hline \multirow{3}{*}{$\begin{array}{l}\text { A. populnea } \\
\left(600 \mathrm{mg} \cdot \mathrm{kg}^{-1}\right)\end{array}$} & Wistar rat & 24 hours & 3 & 4 & 6 & 6 & 4 & 4 & $4.5 \pm 1.22$ \\
\hline & Swiss mice & 48 hours & 1 & 2 & 1 & 2 & 2 & 3 & $1.8 \pm 0.75$ \\
\hline & Swiss mice & 72 hours & 1 & 2 & 0 & 0 & 2 & 2 & $1.1 \pm 0.98$ \\
\hline \multirow{3}{*}{$\begin{array}{l}\text { A. populnea } \\
(900 \text { mg.kg-1) }\end{array}$} & Wistar rat & 24 hours & 7 & 5 & 4 & 6 & 6 & 6 & $5.6 \pm 1.03$ \\
\hline & Swiss mice & 48 hours & 3 & 1 & 3 & 1 & 2 & 3 & $2.1 \pm 0.98$ \\
\hline & Swiss mice & 72 hours & 3 & 1 & 2 & 2 & 2 & 2 & $2.0 \pm 0.63$ \\
\hline Cyclophosphamide & Wistar rat & 24 hours & 21 & 19 & 23 & 27 & 15 & 23 & $21.3 * \pm 4.08$ \\
\hline ENU & Swiss mice & 48 hours & 6 & 7 & 8 & 9 & 12 & 8 & $8.3^{*} \pm 2.0$ \\
\hline ENU & Swiss mice & 72 hours & 7 & 6 & 6 & 9 & 10 & 9 & $7.8^{*} \pm 1.7$ \\
\hline
\end{tabular}

* Significantly different from negative control $(\mathrm{p}<0.001)$.

say. As expected, N-nitroso-N-ethylurea (ENU) agent used as positive control led to some fragmentation and migration of the fragments in the peripheral blood cells, in the SCGE assay. No statistically significant effects on
DNA migration were found at the three extract concentrations tested in blood cells ( $p>0.05$ ). When exposed to the test extract, most of the cells examined on the slides were undamaged (class 0 ), a few cells showed minor 
damage (class 1), and a very few showed a large amount of damage (class 2 and 3). Furthermore, there was no significant difference in DNA migration among the three extract concentrations tested.

Table 2 summarises the results of the analysis of micronucleus in bone marrow cells of Wistar rats and in peripheral blood cells of Swiss mice following treatment with different concentrations of the A. populnea chloroform fraction and controls.

Administration of the A. populnea chloroform fraction did not result in an increase in the average number of polychromatic erythrocytes with micronuclei (MNPCE) in the bone marrow cells of Wistar rats or MNPCE on peripheral blood cells of Swiss mice (Table 2). Comparisons between different dose groups showed no significant differences between the mean MNPCE (Tukey-Kramer test, $\mathrm{p}>0.05$ ).

The MI values obtained from the analysis of 1,000 cells/animal for a sample of 30 animals $(n=6 /$ group) ranged from 1.7 to $4.4 \%$ (means) and statistical analysis by the Tukey-Kramer test showed no significant differences $(\mathrm{p}>0.05)$ between the different treatments with the tested extract, or between these treatments and their controls (Table 3).

Table 3. Mitotic Index (MI) and distribution of the different types of chromosomal aberrations (CA) observed in males (M) Wistar rat bone marrow cells treated with a Austroplenckia populnea chloroform fraction, and respective controls. One hundred cells were analysed per animal, for a total of 600 cells per treatment. C, Chromatid-type; IC, isochromatid-type; OA, other aberrations: del $=$ deletion, $\mathrm{f}=$ fragment; $\mathrm{SDM}=$ standard deviation of the mean.

\begin{tabular}{|c|c|c|c|c|c|c|c|c|}
\hline \multirow[t]{3}{*}{ Treatments } & \multirow[t]{3}{*}{ Animal } & \multirow[t]{3}{*}{ MI (\%) } & \multicolumn{5}{|c|}{ Chromosomal aberrations } & \multirow{2}{*}{$\begin{array}{c}\text { Total }(\mathrm{CA}) \\
\text { without gaps } \\
\end{array}$} \\
\hline & & & \multicolumn{2}{|c|}{ Gaps } & \multicolumn{2}{|c|}{ Breaks } & & \\
\hline & & & $\mathrm{C}$ & $\mathrm{IC}$ & $\mathrm{C}$ & IC & $\mathrm{OA}$ & \\
\hline \multirow{7}{*}{$\begin{array}{l}\text { Control } \\
\text { (Water) }\end{array}$} & $\mathrm{M}_{1}$ & 2.9 & 0 & 0 & 1 & 0 & 0 & 1 \\
\hline & $\mathrm{M}_{2}$ & 2.4 & 0 & 0 & 1 & 0 & 0 & 1 \\
\hline & $\mathrm{M}_{3}$ & 2.0 & 0 & 0 & 0 & 0 & $1 \mathrm{del}$ & 1 \\
\hline & $\mathrm{M}_{4}$ & 1.9 & 1 & 0 & 1 & 0 & 0 & 1 \\
\hline & $\mathrm{M}_{5}^{4}$ & 2.7 & 0 & 0 & 1 & 0 & 0 & 1 \\
\hline & $\mathrm{M}_{6}$ & 2.9 & 1 & 0 & 0 & 0 & $1 \mathrm{del}$ & 1 \\
\hline & mean $\pm \mathrm{SDM}$ & $2.4 \pm 0.44$ & - & - & - & - & - & $1.0 \pm 0.0$ \\
\hline \multirow{7}{*}{$\begin{array}{l}\text { A. populnea } \\
\left(300 \mathrm{mg} \cdot \mathrm{kg}^{-1}\right)\end{array}$} & $\mathrm{M}_{1}$ & 2.4 & 0 & 1 & 0 & 0 & 0 & 0 \\
\hline & $\mathrm{M}_{2}$ & 3.6 & 0 & 0 & 1 & 0 & 0 & 1 \\
\hline & $\mathrm{M}_{3}$ & 1.7 & 0 & 1 & 0 & 0 & 0 & 0 \\
\hline & $\mathrm{M}_{4}$ & 1.8 & 0 & 0 & 1 & 0 & 0 & 1 \\
\hline & $\mathrm{M}_{5}$ & 2.2 & 0 & 0 & 0 & 0 & 0 & 0 \\
\hline & $\mathrm{M}_{6}$ & 2.4 & 0 & 0 & 1 & 0 & 0 & 1 \\
\hline & mean $\pm \mathrm{SDM}$ & $2.3 \pm 0.68$ & - & - & - & - & - & $0.5 \pm 0.54$ \\
\hline \multirow{7}{*}{$\begin{array}{l}\text { A. populnea } \\
\left(600 \mathrm{mg} \cdot \mathrm{kg}^{-1}\right)\end{array}$} & $\mathrm{M}_{1}$ & 2.4 & 1 & 0 & 1 & 0 & 0 & 1 \\
\hline & $\mathrm{M}_{2}$ & 2.4 & 0 & 0 & 1 & 0 & 0 & 1 \\
\hline & $\mathrm{M}_{3}^{2}$ & 3.4 & 0 & 0 & 1 & 0 & 0 & 1 \\
\hline & $\mathrm{M}_{4}$ & 3.6 & 0 & 0 & 0 & 0 & 0 & 0 \\
\hline & $\mathrm{M}_{5}$ & 3.9 & 0 & 1 & 0 & 0 & 0 & 0 \\
\hline & $\mathrm{M}_{6}$ & 2.8 & 1 & 0 & 1 & 0 & 0 & 1 \\
\hline & mean $\pm \mathrm{SDM}$ & $3.0 \pm 0.64$ & - & - & - & - & - & $0.66 \pm 0.51$ \\
\hline \multirow{7}{*}{$\begin{array}{l}\text { A. populnea } \\
\left(900 \mathrm{mg} \cdot \mathrm{kg}^{-1}\right)\end{array}$} & $\mathrm{M}_{1}$ & 2.5 & 0 & 0 & 1 & 0 & 0 & 1 \\
\hline & $\mathrm{M}_{2}$ & 1.9 & 0 & 0 & 0 & 0 & $2 \mathrm{del}$ & 2 \\
\hline & $\mathrm{M}_{3}^{2}$ & 3.2 & 0 & 0 & 0 & 0 & 0 & 0 \\
\hline & $\mathrm{M}_{4}$ & 3.4 & 0 & 0 & 1 & 0 & $1 \mathrm{del}$ & 2 \\
\hline & $\mathrm{M}_{5}$ & 2.0 & 0 & 0 & 0 & 0 & 0 & 0 \\
\hline & $\mathrm{M}_{6}$ & 3.1 & 0 & 0 & 1 & 0 & 0 & 1 \\
\hline & mean \pm SDM & $2.6 \pm 0.64$ & - & - & - & - & - & $1.0 \pm 0.89$ \\
\hline \multirow{7}{*}{$\begin{array}{l}\text { Cyclophosphamide } \\
\left(50 \mathrm{mg} \cdot \mathrm{kg}^{-1}\right)\end{array}$} & $\mathrm{M}_{1}$ & 2.2 & 0 & 3 & 0 & 0 & 0 & 3 \\
\hline & $\mathrm{M}_{2}$ & 3.5 & 4 & 0 & 3 & 0 & $2 \mathrm{f}$ & 5 \\
\hline & $\mathrm{M}_{3}$ & 4.4 & 3 & 0 & 6 & 0 & $3 \mathrm{del} / 1 \mathrm{f}$ & 10 \\
\hline & $\mathrm{M}_{4}$ & 3.9 & 1 & 1 & 3 & 1 & $1 \mathrm{del}$ & 5 \\
\hline & $\mathrm{M}_{5}$ & 3.2 & 0 & 1 & 3 & 2 & $1 \mathrm{del}$ & 6 \\
\hline & $\mathrm{M}_{6}$ & 3.3 & 1 & 1 & 4 & 1 & $1 \mathrm{del}$ & 6 \\
\hline & mean \pm SDM & $3.4 \pm 0.74$ & - & - & - & - & - & $5.83 * \pm 2.31$ \\
\hline
\end{tabular}

*Significantly different from negative control $(\mathrm{p}<0.001)$. 
The data obtained from 100 metaphase cells/animal also showed that there were no statistically significant differences between the mean number of chromosome aberrations for the treated groups and the negative control ( $\mathrm{p}>0.05)$. The most frequent types of aberrations in the treated groups were chromatid breaks, deletions, and isochromatid gaps (Table 3).

\section{Discussion}

In this study, the animals were submitted to acute treatment via gavage of the Austroplenckia populnea chloroform fraction, obtained from its hydroalcoholic barkwood extract. This treatment regimen and the administration method were considered the most suitable because they were closer to the form in which A. populnea extracts are ingested by the population.

The comet assay (SCGE) has been used as a rapid and sensitive tool for detecting primary DNA damage in individual cells. This technique enables the detection of several classes of DNA injury, such as doublestrand breaks, single strand-breaks, alkali-labile sites, incomplete repair of a-basic sites and cross-links (Singh et al., 1988; Rojas et al., 1999; Brendler-Schwaab et al., 2005). In the present study, the comet assay was used as an additional comparison method with micronucleus and chromosome aberration assays and showed a slight increase in total damaged cells and the scores in animal groups treated with the A. populnea chloroform fraction, but the results did not differ significantly from the negative control group, indicating no genotoxic effects of this extract fraction.

The micronucleus (MN) assay in rodents is the bestdocumented in vivo test on clastogenic effects (chromosome aberrations), in relation to the number of tested chemicals (Mavournin et al., 1990; Morita et al., 1997) and chromosome aberration test is an important cytogenetic endpoint that is routinely used to evaluate genotoxicity (Preston et al., 1987; Krishna et al., 1991). In the present study, it was demonstrated that three high doses of A. populnea chloroform fraction from crude barkwood extract showed no increase in the mean number of micronucleated erythrocytes in the peripheral blood of mice, and the bone marrow of rats, and no chromosomal aberrations in the bone marrow cells of Wistar rats. The mitotic index values obtained indicate that this fraction extract has no cytotoxic effects at the tested doses. These data contrast with the results obtained by Zanoni et al. (2005), in which crude barkwood extract from A. populnea induced a significant dose-related increase in mean chromosomal aberrations at the 600 and $900 \mathrm{mg} \cdot \mathrm{kg}^{-1}$ doses, and also a dose related increase in the mean MNPCE at the 300, 600 and $900 \mathrm{mg} \cdot \mathrm{kg}^{-1}$ doses in the bone marrow cells of Wistar rats. On the other hand, Pugliesi et al. (2007) observed that the leaf extract of A. populnea did not induce a decrease in the mitotic index, neither did it induce a statistically significant increase in the mean number of MNPCE or chro- mosome aberrations in the bone marrow cells of Wistar rats at doses of 300,600 and $900 \mathrm{mg} \cdot \mathrm{kg}^{-1}$. The quantitative differences in chemical composition between the stalk and leaf extracts obtained from A. populnea (the barkwood extract is richer in triterpenes than the leaf extract; S. F. Andrade, personal communication) could explain the differences in clastogenic potential observed between these 2 extracts. Similarly, qualitative and quantitative differences between $A$. populnea crude barkwood extract and their chloroform fraction could explain the differences in micronucleus induction observed between these two extracts.

In conclusion, analysing the available data on the genotoxic/clastogenic potential of A. populnea extracts obtained by Zanoni et al. (2005), Pugliesi et al. (2007), and in the present work, all developed in our laboratory, we observe that A. populnea crude bark wood extract shows a slight but significant increase in clastogenicity in the bone marrow cells of Wistar rats (Zanoni et al., 2005), however, the chloroform fraction of this extract shows no genotoxic or clastogenic/aneugenic effects in the bone marrow cells of Wistar rats and in the peripheral blood cells of Swiss mice (present study). A. populnea leaf extract does not present any clastogenic/aneugenic effects on Wistar rats cells (Pugliesi et al., 2007). These data do not preclude the therapeutic consumption of $A$. populnea extracts, but demonstrate that caution is needed in their indiscriminate use, until the other extract fractions (hexane and ethyl acetate) have been studied and the relationship between the qualitative and quantitative analyses of each extract/fraction and their mutagenic potential can be better investigated.

Acknowledgements - We would like to thank the Brazilian agencies CNPq (306544/2006-7), FAPESP (2006/57514-2) and FAPEMIG (Rede Mineira de Ensaios Toxicológicos e Farmacológicos de Produtos Terapêuticos, EDT - 1879/02) for the financial support for this study and Lucimara Maria da Silva for the technical assistance.

\section{References}

ARAÚJO, MCP., DIAS, FL., KRONKA, SN. and TAKAHASHI, CS. 1999. Effects of turmeric and its active principle, curcumin, on bleomycin-induced chromosome aberrations in Chinese hamster ovary cells. Genetics and Molecular Biology, vol. 22, no. 3, p. 407-413.

BRENDLER-SCHWAAB, S., HARTMANN, A., PFUHLER, S. and SPEIT, G. 2005. The in vivo comet assay: use and status in genotoxicity testing. Mutagenesis, vol. 20, no. 4, p. 245-254.

BURIM, RV., CANALLE, R., LOPES, JLC. and TAKAHASHI, CS. 1999. Genotoxic action of the sesquiterpene lactone glaucolide B on mammalian cells in vitro and in vivo. Genetics and Molecular Biology, vol. 22, no. 3, p. 401-406.

CHACON,DR.,LIBERA,AND., CINTRA,DEC.,CARVALHO, JCT., OLIVEIRA, GA. and MAISTRO, EL. 2002. Absence of genotoxic and antigenotoxic effects of a standardized extract of the medicinal plant Solanum melongena on peripheral blood and bone marrow cells of Wistar rats. Cytologia, vol. 67, no. 4, p. 417-422. 
CORRÊA, MP. 1985. Dicionário das plantas úteis do Brasil e das plantas exóticas cultivadas. Rio de Janeiro: Imprensa Nacional. vol. 6, p. 1926-1978.

ESPÓSITO, AV., PEREIRA, DMV., ROCHA, LM., CARVALHO, JCT. and MAISTRO, EL. 2005. Evaluation of the genotoxic potential of the Hypericum brasiliense (Guttiferae) extract in mammalian cell system in vivo. Genetics and Molecular Biology, vol. 28, no. 1, p. 152-155.

FORD, CE. and HAMERTON, JL. 1956. A colchicine, hypotonic citrate, squash sequence for mammalian chromosomes. Stain Technology, vol. 31, no. 6, p. 247-251.

HARTMANN, A. and SPEIT, G. 1997. The contribution of cytotoxicity to DNA-effects in the single cell gel test (comet assay). Toxicology Letters, vol. 90, no. 2-3, p. 183-188.

KLAUDE, M., ERIKSSON, S., NYGREN, J. and AHNSTRÖM, G. 1996. The comet assay: mechanisms and technical considerations. Mutation Research, vol. 363, no. 2, p. 89-96.

KRISHNA, G., KROPKO, ML., CIARAVINO, V. and THEISS, JC. 1991. Simultaneous micronucleus and chromosome aberration assessment in the rat. Mutation Research, vol. 264, no. 1, p. 29-35.

MACGREGOR, JT., WEHR, CM. and GOULD, DH. 1980. Clastogen-induced micronuclei in peripheral blood erythrocytes: the basis of an improved micronucleus test. Environmental Mutagenesis, vol. 2, no. 4, p. 509-514.

MAISTRO, EL., CARVALHO, JCT., CASCON, V. and KAPLAN, MAC. 2005. In vivo evaluation of the mutagenic potential and phytochemical characterization of oleoresin from Copaifera duckei Dwyer. Genetics and Molecular Biology, vol. 28 , no. 4 , p. $833-838$.

MAVOURNIN, KH., BLAKEY, DH., CIMINO, MC., SALAMONE, MF. and HEDDLE, JA. 1990. The in vivo micronucleus assay in mammalian bone marrow and peripheral blood. A report of the U.S. Environmental Protection Agency Gene-Tox Program. Mutation Research, vol. 239, no. 1, p. $29-80$.

MORITA, T. 1997. Evaluation of the rodent micronucleus assay in the screening of IARC carcinogens (Group 1. 2A and 2B). The summary report of the $6^{\text {th }}$ collaborative study by CSGMT/ JEMS MMS. Mutation Research, vol. 389, no. 1, p. 3-122.
PRESTON, RJ., DEAN, BJ., GALLOWAY, S., HOLDEN, H., MCFEE, AF. and SHELBY, M. 1987. Mammalian in vivo cytogenetic assays: analysis of chromosome aberrations in bone marrow cells. Mutation Research, vol. 189, no. 2, p. 157-165.

PUGLIESI, GC., ANDRADE, SF., BASTOS, JK. and MAISTRO, EL. 2007. In vivo clastogenicity assessment of the Austroplenckia populnea (Celastraceae) leaves extract using micronucleus and chromosome aberration assay. Cytologia, vol. 72 , no. 1, p. 1-6.

ROJAS, E., LOPEZ, MC. and VALVERDE, M. 1999. Single cell gel electrophoresis assay: methodology and applications. Journal of Chromatography B, vol. 722, no. 1-2, p. 225-254.

SAVAGE, JRK. 1976. Classification and relationships of induced chromosomal structural changes. Journal of Medical Genetics, vol. 13, no. 2, p. 103-122.

SCHMID, W. 1976. The micronucleous test for cytogenetic analysis. In Hollaender, A. (Ed.) Chemical mutagenesis: principles and methods for their detection. vol. 4. New York: Plenum Press. p. 31-53.

SEITO, LN., MAZARO, R. and Di-STASI, LC. 2002. Antiulcerogenic and analgesic effects of the Austroplenckia populnea extracts in mice. Phytotherapy Research, vol. 16, no. 2, p. 193-196.

SINGH, NP., MCCOY, MT., TICE, RR. and SCHNEIDER, EL. 1988. A simple technique for quantitation of low levels of DNA damage in individual cells. Experimental Cell Research, vol. 175 , no. 1, p. 184-191.

SPEIT, G. and HARTMANN, A. 1999. The comet assay (singlecell gel test). In Henderson, DS. (Ed.). Methods in molecular biology, vol. 113. New York: Humana Press. p. 203-212.

SOKAL, RR. and ROHLF, FJ. 1995. In FREEMAN, WH. (Ed.). San Francisco: Biometry. p. 175-486.

VIEIRA-FILHO, AS., DUARTE, LP., SILVA GDF., LULA IS. and SANTOS MH. 2001. Total assignment of $1 \mathrm{H}$ and 13C NMR spectra of two 3,4-secofriedelanes from Austroplenckia populnea. Magnetic Resonance in Chemistry, vol. 39, no. 12, p. $746-748$.

ZANONI, FD., ANDRADE, SF., BASTOS, JK. and MAISTRO, EL. 2005. Clastogenicity of the Austroplenckia populnea (Celastraceae) bark wood extract in Wistar rat bone marrow cells. Cytologia, vol. 70, no. 3, p. 303-308. 